난난, BANCO CENTRAL DO BRASIL

Expectations Anchoring Indexes for Brazil using Kalman Filter: exploring signals of inflation anchoring in the long term

Fernando Nascimento de Oliveira and Wagner Piazza Gaglianone

August 2019

Working Papers
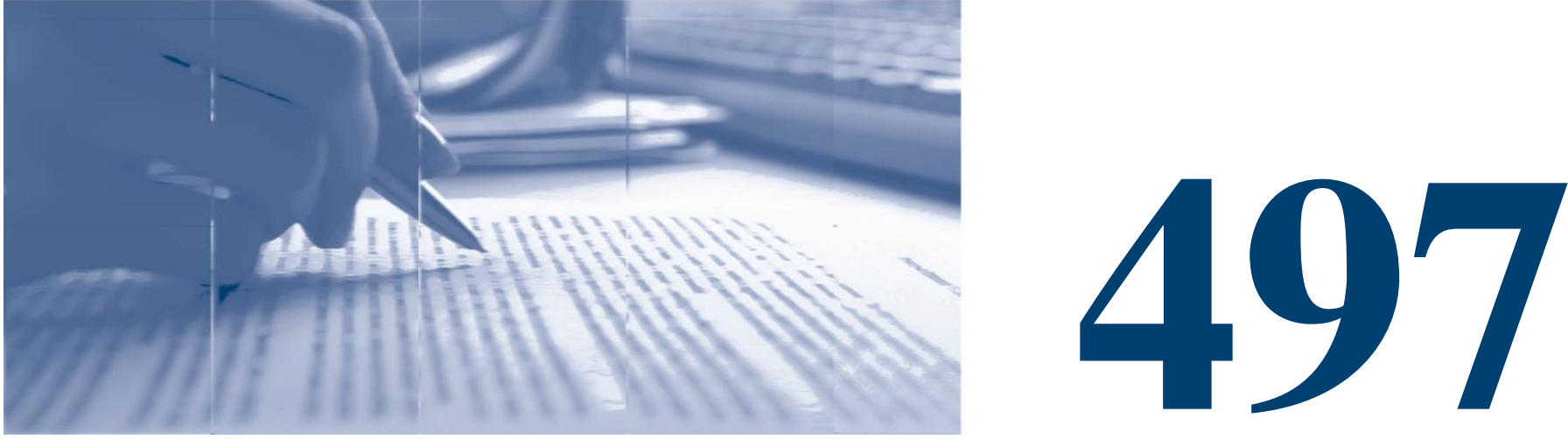
ISSN 1518-3548

CGC 00.038.166/0001-05 


\section{Working Paper Series}

Edited by Research Department (Depep) - E-mail: workingpaper@bcb.gov.br

Editor: Francisco Marcos Rodrigues Figueiredo - E-mail: francisco-marcos.figueiredo@bcb.gov.br

Co-editor: José Valentim Machado Vicente - E-mail: jose.valentim@bcb.gov.br

Head of Research Department: André Minella - E-mail: andre.minella@bcb.gov.br

The Banco Central do Brasil Working Papers are all evaluated in double blind referee process.

Reproduction is permitted only if source is stated as follows: Working Paper n. 497.

Authorized by Carlos Viana de Carvalho, Deputy Governor for Economic Policy.

\section{General Control of Publications}

Banco Central do Brasil

Comun/Divip

SBS - Quadra 3 - Bloco B - Edifício-Sede - $2^{\circ}$ subsolo

Caixa Postal 8.670

70074-900 Brasília - DF - Brazil

Phones: +55 (61) 3414-3710 and 3414-3565

Fax: +55 (61) 3414-1898

E-mail: identidadevisual.comun@bcb.gov.br

The views expressed in this work are those of the authors and do not necessarily reflect those of the Banco Central or its members.

Although these Working Papers often represent preliminary work, citation of source is required when used or reproduced.

As opiniões expressas neste trabalho são exclusivamente do(s) autor(es) e não refletem, necessariamente, a visão do Banco Central do Brasil.

Ainda que este artigo represente trabalho preliminar, é requerida a citação da fonte, mesmo quando reproduzido parcialmente.

\section{Citizen Service Division}

Banco Central do Brasil

Deati/Diate

SBS - Quadra 3 - Bloco B - Edifício-Sede - 2º subsolo

70074-900 Brasília - DF - Brazil

Toll Free: 08009792345

Fax: +55 (61) 3414-2553

Internet: http//www.bcb.gov.br/?CONTACTUS 


\section{Non-technical Summary}

Inflation expectations play a key role in monetary policy, and the actual impact of monetary policy depends largely on its effects on anchoring inflation expectations. Indeed, the formation process of inflation expectations lies at the center of any definition of central bank credibility.

A credible commitment to an explicit inflation objective helps to anchor inflation expectations to the desired level and, thus, contributes to delivering price stability, which is the main objective of central banks.

This paper provides a new method to construct expectations anchoring indexes that are fundamentally driven by the monetary authority's capacity to anchor long-term inflation expectations vis-à-vis short-run inflation expectations.

An empirical exercise illustrates the method using Brazilian data, in which the expectations anchoring indexes are built from a set of 31 signals using inflation expectations from the Focus survey of professional forecasters, conducted by the Central Bank of Brazil (BCB), as well as from the swap and federal government bond markets.

Altogether, these signals provide relevant daily information on the degree of anchoring of inflation expectations. The empirical results show that the novel expectations anchoring indexes that we propose using such signals, although varying across specifications, tend to display a downward trajectory, more clearly in 2009 , and show a recovery starting in 2016 until the end of the sample (mid-2017). 


\section{Sumário Não Técnico}

As expectativas de inflação desempenham um papel fundamental na condução da política monetária, e o impacto efetivo da política monetária depende, em grande medida, dos seus efeitos na ancoragem das expectativas de inflação. Nesse sentido, o processo de formação de expectativas de inflação está no centro de qualquer definição de credibilidade de banco central.

Um compromisso crível com um objetivo explícito relacionado à inflação ajuda a ancorar as expectativas de inflação ao nível desejado e, consequentemente, contribui para a estabilidade de preços, que é o objetivo primordial dos bancos centrais.

Este artigo apresenta um novo método para construir índices de ancoragem de expectativas, que são fundamentalmente determinados pela capacidade da autoridade monetária em ancorar expectativas de inflação no longo prazo em relação às expectativas de inflação de curto prazo.

Um exercício empírico ilustra o método proposto com dados brasileiros, no qual os índices de ancoragem de expectativas são construídos a partir de um conjunto de 31 sinais, utilizando tanto expectativas de inflação da pesquisa Focus, organizada pelo Banco Central do Brasil (BCB), como dados dos mercados de swaps e títulos do governo federal.

Conjuntamente, tais sinais fornecem informação diária relevante sobre o grau de ancoragem das expectativas de inflação. Os resultados empíricos mostram que os índices de ancoragem de expectativas propostos, utilizando tais sinais, apesar de apresentarem dinâmicas distintas ao longo das diferentes especificações, tendem a exibir uma trajetória declinante, principalmente em 2009, e mostram uma recuperação desde 2016 até o final da amostra (em meados de 2017). 


\title{
Expectations Anchoring Indexes for Brazil using Kalman Filter: exploring signals of inflation anchoring in the long term *
}

\author{
Fernando Nascimento de Oliveira ${ }^{\mathrm{i}}$ \\ Wagner Piazza Gaglianone ${ }^{\text {ii }}$
}

\begin{abstract}
Our objective in this paper is to build expectations anchoring indexes for inflation in Brazil that are fundamentally driven by the monetary authority's capacity to anchor long-term inflation expectations vis-à-vis short-run inflation expectations. The expectations anchoring indexes are generated from a Kalman filter, based on a state-space model that also takes into account fiscal policy dynamics. The model's signals are constructed using inflation expectations from the Focus survey of professional forecasters, conducted by the Central Bank of Brazil, and from the swap and federal government bond markets, which convey daily information of long-term inflation expectations. Although varying across specifications, the expectations anchoring indexes that we propose tend to display a downward trajectory, more clearly in 2009, and show a recovery starting in 2016 until the end of the sample (mid-2017).
\end{abstract}

Keywords: inflation, expectation, anchoring, Kalman filter, Brazil

JEL Classification: E50, E52, E58

The Working Papers should not be reported as representing the views of the Banco Central do Brasil. The views expressed in the papers are those of the author(s) and do not necessarily reflect those of the Banco Central do Brasil.

\footnotetext{
* This research was undertaken within the framework of CEMLA's Joint Research Program 2017 coordinated by the Banco de la República. We are especially grateful for the helpful comments and suggestions given by Olivier Coibion. We benefited from comments made by participants in the workshop on inflation expectations, their measurement and degree of anchoring at CEMLA headquarters (Mexico City, September 14-15, 2017). We also thank Carlos Viana de Carvalho, André Minella and Bernardus Doornik for comments made at the Second Network of Economic Research of the Central Bank of Brazil.

${ }^{\mathrm{i}}$ Research Department, Central Bank of Brazil and IBMEC/RJ. E-mail: fernando.nascimento@ bcb.gov.br

ii Research Department, Central Bank of Brazil. E-mail: wagner.gaglianone@bcb.gov.br
} 


\section{Introduction}

Well-anchored inflation expectations are fundamental for the conduct of monetary policy. Properly anchoring inflation expectations requires the central bank to be regarded as credible, that is, economic agents should be confident that the central bank will react to the various shocks that affect the economy to maintain price stability.

Cukierman and Meltzer (1986) stressed that future objectives of central banks depend on inflation expectations. In this sense, a credible commitment to an explicit inflation objective helps to anchor inflation expectations to the desired level. This anchoring contributes to delivering price stability, which is the main objective of central banks.

In turn, Blinder (2000) sent questionnaires to 127 heads of central banks around the world asking their opinion on the importance of central bank credibility. The answers showed clearly that credibility matters in practice. A credible central bank is one that can make a believable commitment to low inflation policy and has complete dedication to price stability. This will make disinflation less costly and decrease the sacrifice ratio.

Nonetheless, building credibility is costly and takes repeated successes to establish it. Moreover, credibility evolves in asymmetric fashion and can be lost rapidly, depending on the perception by economic agents that the central bank is able (or not) to achieve its objectives. As famously put by Benjamin Franklin: "It takes many good deeds to build a good reputation, and only one bad one to lose it."

Central banks have imperfect control over inflation in the short run. As Gomme (2006) remarked, current inflation provides a noisy signal of a central bank's long-term intentions, and therefore of its type. According to the author, a central bank is credible when the public assigns a high probability of low inflation-type to the central bank. In this context, a central bank will lose credibility when this probability decreases. The credibility of central banks is very much concerned with people's beliefs about what the central bank will do in the future.

\footnotetext{
${ }^{1}$ See Isaacson (2004).
} 
On the other hand, central bank credibility is a latent variable ${ }^{2}$ and, consequently, it is not easy to measure in practice. One possibility is to look for measures that reflect the capacity central banks have to anchor inflation expectations. In the literature, this is done mostly by looking at how closely short-run expectations match the central bank's explicit or implicit inflation target (see Bordo and Siklos, 2015). The problem with these measures, in our view, is that other signals can exist in the economy that may also help to give an idea of how well inflation expectations are anchored.

Figure 1 compares the consensus inflation forecast in Brazil (horizon of 1 year) with the inflation target and respective tolerance bands. Based on these series, Figure 2 shows the evolution of some credibility indexes (CIs) for the Central Bank of Brazil (hereafter BCB) from January 2002 to June 2017. The measures are, respectively, CI-CK (Cecchetti and Krause, 2002), CI-M (Mendonça, 2004) and CI-MS (Mendonça and Souza, 2009).

These indexes measure deviations of short-run inflation expectations from the inflation target. ${ }^{3}$ For instance, note that at the end of 2002, before the presidential election, these indexes had a substantial decline in credibility. This fact can be related to an exogenous shock to the BCB: the uncertainty about the policy regime with a likely victory of the presidential candidate Lula, which triggered the country sovereign risk premium $(\mathrm{Embi}+\mathrm{Br})$ to sharply rise during this period. This was a situation completely out of the BCB's control. ${ }^{4}$

Also, note that Figure 2 shows a very volatile CI-M, considering the whole sample, indicating a fast loss and recovery of credibility. The other indexes show different behavior of credibility: CI-CK varies very little, while CI-MS looks constant almost all the time. In fact, the credibility dynamics implied by these indexes seem not to appropriately represent the dynamics of mean and standard deviation inflation expectations measured in fixed horizons and taken from the BCB's daily survey of expectations (Focus), presented in Figure 5. The upper-left graph shows that the cross-sectional mean of inflation expectations with forecast horizon of four

\footnotetext{
${ }^{2}$ The international literature on credibility indexes of central banks is vast. There are many theoretical as well as empirical papers on the subject. See, for example, Gomme (2006), Svensson (1993), Clarida and Waldman (2007), Ceccheti and Krause (2002), Kaseeream (2012) and Bordo and Siklos (2015).

${ }^{3}$ Other papers also build credibility indexes for the Central Bank of Brazil focusing on deviations of short-term inflation expectations from inflation target, such as Teles and Nemoto (2005), Sicsú (2002), Nahon and Meurer (2005) and Lowenkron and Garcia (2007).

${ }^{4}$ Note that CI-M decreases substantially during the subprime crisis, which like Lula's election is also exogenous to the $\mathrm{BCB}$. At the end of the period, CI-M shows a steep credibility recovery that also seems counterfactual.
} 
years - a measure of long term expectations - has much less volatility than the one-year (shortterm) inflation expectations. Not only that, but in the run-up to Lula's election and the subprime crises, the four-year expectations varied much less than the one-year counterpart. The lower-left graph of Figure 5 shows a similar dynamic pattern for the short-run (one year) and long-run (four years) standard deviation of inflation expectations. ${ }^{5}$

In practice, one should examine a variety of signals to construct a measure that really reflects the ability of central banks to anchor inflation expectations (see Demertzis et al., 2012). We think that the problem with most traditional CIs available in the literature is that they focus on the short-run deviations of inflation expectations from the inflation target. In contrast, we construct in this paper expectations anchoring indexes (hereafter, EAIs) that are specifically designed to measure the degree of anchoring of long-term inflation expectations vis-à-vis the short-run.

The bottom-line of our argument is that a central bank is credible if it has the capability to properly anchor long-run inflation expectations. The extent of long-term inflation anchoring will serve as proxy for anchoring. If the central bank is credible and anchors long-term inflation expectations, then the long-run expectations will become less responsive to shortrun economic news. ${ }^{6}$ This means that in the presence of a negative or positive short-term shock to inflation, economic agents believe the central bank will take appropriate countervailing actions to keep inflation on target in the long run.

Our view is in line with Demertzis et al. (2012) and Buono and Formai (2016). Demertzis et al. (2012) point out that credibility of the central bank decouples long-run inflation expectations from short-run expectations. Buono and Formai (2016) notice that inflation expectations are anchored when movements in short-run expectations do not affect movements in long-term. ${ }^{7}$

\footnotetext{
${ }^{5}$ There are other papers in the literature that build credibility indexes for the Central Bank of Brazil taking different approaches from those that look at short-term deviations of inflation expectations from the target. This is the case of Garcia and Guillén (2011), Leal et al. (2012), Issler and Santos (2017) and Val et al. (2017).

${ }^{6}$ Bernanke (2007) describes inflation anchoring in the following manner: "..." anchored" to mean relatively insensitive to incoming data. So, for example, if the public experiences a spell of inflation higher than their longrun expectation, but their long-run expectation of inflation changes little as a result, then inflation expectations are well anchored. If, on the other hand, the public reacts to a short period of higher-than-expected inflation by marking up their long-run expectation considerably, then expectations are poorly anchored".

${ }^{7}$ For other empirical papers with definitions of credibility, see Davis (2012), Levieuge et al. (2015) and Dimitris et al. (2016). For theoretical papers with definitions of central bank credibility, see Barro and Gordon (1983), Walsh (1995) and Blackburn and Christensen (1989).
} 
To build expectations anchoring indexes for inflation in Brazil that decouple long-term from short-term inflation expectations, we also need to incorporate explicitly in our approach some measure of fiscal policy. The reason is that, in some periods in Brazil, perceptions about fiscal policy and fiscal sustainability seemed to have played an important role in explaining inflation expectations. If we do not control for that, processes of deanchoring of expectation may be attributed to the BCB's policies and not to broader economic policies. In emerging countries where the public debt is high (in terms of GDP) and with short average maturity, periods of fiscal dominance may occur.

As Sargent and Wallace (1981) argue, under fiscal dominance, the monetary authority faces the constraints imposed by the demand for government bonds. If the fiscal authority cannot finance its deficits solely by new bond sales, then the monetary authority is forced to create money and tolerate additional inflation. Although such a monetary authority might still be able to control inflation over the long run, it is less capable than a monetary authority under a no fiscal dominance situation. Blanchard (2004) argues that fiscal dominance describes the situation of the Brazilian economy in 2002 and 2003.

In periods of fiscal dominance, there may be a reversal of the traditional roles of monetary and fiscal policies: central banks are inclined to reduce interest rates when inflation rises, the opposite of their standard response, in order to guarantee the stability and solvency of debts and deficits. Therefore, in such periods even a credible central bank may find difficulty in keeping long-term inflation expectations unaffected by short-term shocks on inflation or short-term inflation expectations.

Our objective in this paper is to build EAIs that are fundamentally driven by the capacity the $\mathrm{BCB}$ has to anchor long-term inflation expectations vis-à-vis short-run expectations. The EAIs will be constructed from a Kalman filter, based on a linear state-space model that also takes into account fiscal policy dynamics. The signals of the state-space model will give information on the degree of anchoring of long-term inflation expectations. 
There are many possible signals of long-term inflation anchoring in the literature, ${ }^{8}$ based on nonparametric or parametric approaches. We use as many signals as possible from all sources that are available. In this sense, we have disaggregated daily data (from January 2002 to June 2017) of inflation expectations from the Focus survey of professional forecasters conducted by the BCB. From this survey, we extracted 17 signals. We also have market data of nominal federal government bonds (Letras do Tesouro Nacional, hereafter LTN) and inflation-indexed bonds (Notas do Tesouro Nacional, hereafter NTN-B) from April 2005 to June 2017. Finally, we have information on swaps of fixed interest rate instruments against inflation from January 2005 to June 2017. From the bond and swap markets, we extracted 14 signals.

We contribute to the literature in several manners. Firstly, as far as we know, this is the first paper to use a large number of signals of long-term inflation expectation anchoring, coming from both surveys and market data. Secondly, we focus on long-term inflation expectations, unlike the great majority of empirical papers on the subject in Brazil. ${ }^{9} \mathrm{We}$ can update our EAIs on a daily basis with disaggregated and aggregated data obtained through surveys or through market information. By construction, our EAIs give a prompt idea of how well the long-term inflation expectations are anchored, which is very important in the implementation of monetary policy, especially in an inflation targeting regime.

In the third place, we take into account both fiscal policy and monetary policy when estimating the state-space model using our survey and market data for long-term inflation expectation anchoring compared to short-run inflation expectations. Finally, the disaggregated confidential survey data of the BCB - an essential part of our database - is unique and enables us to have a much better grasp of inflation expectations of economic agents in Brazil, and hence of the BCB's ability to anchor them.

The rest of the paper is organized as follows: Section 2 describes the data; Section 3 presents the empirical analyses; and Section 4 concludes.

\footnotetext{
${ }^{8}$ See Natoli and Sigalotti (2017).

${ }^{9}$ See Gaglianone (2017) for a recent survey of applied research on inflation expectations in Brazil.
} 


\section{Data}

We have survey and market data. In the former case, we have data from January 2002 to June 2017. In the latter case, we have data from April 2005 to June 2017.

Our survey data are proprietary, with confidential information at the individual level and publicly available data at aggregate level. The data were obtained from the Focus survey organized by the $\mathrm{BCB}$, collected every workday by the $\mathrm{BCB} .{ }^{10} \mathrm{We}$ have the distribution of inflation expectations for every workday.

We have unbalanced panel data of survey inflation expectations. The number of registered institutions that take part in the survey is 277 in our sample. The number of workdays in our sample is 3,781 . The average number of institutions that report inflation forecasts is 83 for the forecast horizon of one year and 48 for the four-year horizon.

Figure 3 presents the number of institutions that forecast inflation every workday for one year up to five years. As can be seen, there are some workdays on which very few institutions reported. This is particularly relevant in the case of forecasts for four or five years. In addition, for each end-of-year inflation, the number of institutions reporting forecasts increases as long as the forecast horizon diminishes. To avoid problems in our estimations, we consider that when there were fewer than 10 institutions reporting on a certain workday, we repeat the forecasts of the previous workday in which there were more than 10 institutions reporting for the same period.

Raw information on inflation expectations pertains to fixed events (e.g., end-of-year inflation forecasts for the current and following years); see Figure 4. We transform them to fixedhorizon inflation expectations by linear interpolation using the daily (decreasing) forecast horizon of the fixed-event inflation forecasts; see Figure 5. Since the longest horizon of inflation forecasts available in the Focus survey involves the five-year ahead forecast (calendar year), we employ the inflation expectations for the following four and five calendar years to build the interpolated forecast with a maximum fixed horizon of four years.

\footnotetext{
${ }^{10}$ Nowadays, the BCB releases on the internet the micro data of the Focus survey of expectations, in a panel data with fake IDs (i.e., the identity of the survey participants is preserved and the disclosed database only contains anonymous participants). For more details, see the website: http://dadosabertos.bcb.gov.br/dataset/expectativasmercado/resource/23f6c983-f9bd-48f8-a889-72def3ae17c8
} 
On the other hand, there is no inflation target set for such long horizons. Since the beginning of the inflation targeting regime in 1999 and up to the inflation target announced for 2019, the inflation target and tolerance bands had been set up to June of year $t$ for the calendar year $t+2$. Nowadays, the new target is announced up to June of year $t$ for the calendar year $t+3 .{ }^{11}$ Since many signals depend on the inflation target, and since our longest forecast horizon is four years, we assume that the inflation target four years ahead is equal to the target set for the calendar year $t+2$ (or $t+3$, whenever available).

In the case of market data, we have publicly available information on federal government bonds and swaps of fixed interest rate against inflation and a coupon from April 2005 to June 2017. The former are obtained from Anbima (Brazilian Financial and Capital Market Association) and the latter are registered by B3 (a Brazilian company that operates securities, commodities and futures exchange, among others, previously known as BM\&FBovespa). Federal government bonds are nominal bonds (LTNs) and inflation-indexed bonds (NTN-Bs). The yields of these bonds for different maturities are calculated by fitting LTN and NTN-B with the Nelson-Siegel-Svensson functional form.

The difference between yields of the same maturity of LTNs and NTN-Bs is known as breakeven inflation (hereafter BEI). According to Shen (2006): "An increase in the breakeven rate is sometimes viewed as a sign that market inflation expectations may be on the rise. For example, the FOMC frequently refers to the yield spread as a measure of inflation compensation' and considers the yield spread an indicator of inflation expectations in policy deliberations." 12 In this paper, we use BEI series as proxies of market inflation expectations. It is important to note that these measures are embedded with a liquidity premium as well as an inflation risk premium that might distort it from pure measures of inflation expectations.

Swaps of inflation plus a coupon against fixed interest rates are registered by B3. The BCB collects workday information in this respect. The difference between fixed rate and coupon gives BEIs of swaps. One advantage of BEIs coming from swaps - compared to BEIs from federal government bonds - is that they have very low liquidity premiums. ${ }^{13}$ Figure 6 shows

\footnotetext{
${ }^{11}$ See https://www.bcb.gov.br/pec/metas/InflationTargetingTable.pdf

${ }^{12}$ FOMC means the Federal Open Market Committee of the U.S. Federal Reserve.

${ }^{13}$ We have yields for fixed-interest bonds with maturities of one, three and ten years. We interpolate linearly the three- and ten-year yields to get the four-year yields that we used to construct BEIs for the swap market.
} 
the dynamics of BEI from swaps and federal government bonds with maturities of one and four years.

In both Figures 5 and 6, it is easy to observe that four-year survey inflation expectations and four-year BEIs have lower variance and are more persistent than one-year inflation expectations and one-year BEIs, respectively.

As for an indicator of high frequency fiscal policy, we use workday expectations of primary balance as a percentage of GDP. These data are also collected from the Focus survey. We use in our empirical analyses the one-year ahead expectations. The raw data on the expectations are for fixed events and we transform them for a fixed horizon by linear interpolation in exactly same way as we do for inflation expectations.

Figure 7 shows the dynamics of this series. As can be seen, there is a clear turning point in fiscal expectations in our sample. Until 2009, the expectations were relatively stable around a primary surplus of 4\% of GDP. From mid-2009 until mid-2012, expectations fluctuated near a primary surplus of 3\% of GDP. However, from mid-2012 on there was clear deterioration of these expectations, reaching a primary balance of -2\% of GDP in the beginning of 2017.

\section{Empirical Analysis}

Our method to construct the expectations anchoring indexes can be summarized as follows:

(i) build a set of normalized (i.e., zero mean and unit variance) signals from both survey and market data;

(ii) employ factor analysis to summarize the panel data information of signals into a single "common factor" series that contains the core dynamics of long-term inflation expectation anchoring in respect to the short-run inflation expectations;

(iii) estimate a state-space model using a Kalman filter to build two separate states for monetary policy and fiscal stance; and

(iv) employ a logit transformation to set the scale of states into the $[0 ; 1]$ interval.

We next describe the signals of long-term inflation anchoring that we used in the paper. 


\subsection{Signals of long-term inflation anchoring}

Some of our signals are based on recursive correlations or recursive regressions. In these cases, we used a training sample of six months (126 workdays) in order to generate the first signal observation. Moreover, we treated the observations of our recursive analyses in three different ways: each observation was weighted by exponentially smoothed weights with a half-life of one or two years ${ }^{14}$, or by using a rolling window of three years. Moreover, all the signals that we used to build our EAIs were normalized z-scores (i.e., with zero mean and standard deviation equal to one).

\subsubsection{Signals from survey data}

Table 1 lists the signals that we extracted from the BCB survey. We built signals based on recursive Pearson correlation and recursive ordinary least squares (OLS) of mean and median four-year inflation expectations against one-year inflation expectations. We also built signals based on recursive correlations and recursive OLS between the standard deviation and interquartile range of four- and one-year inflation expectations. In the case of regressions, our signals are the slope coefficients of the regressors related to one-year inflation expectations.

We built a signal based on the estimation of time-varying VAR as in Demertzis et al. (2012). The estimation is based on Stock and Watson (1996). The coefficients vary through time like random walks. The coefficient of interest is the one that measures the elasticity of four-year inflation expectations in relation to one-year inflation expectations.

We built two signals based on the evolution of the distribution of the four-year inflation expectations. One signal is equal to 0 if the median of the distribution is equal to the inflation target and 1 otherwise. The other signal is equal to 0 on workday $t$ if the distribution on this day is equal to the distribution on workday $t-21$ (previous month) and 1 otherwise, based on the Kolmogorov-Smirnov test. ${ }^{15}$

\footnotetext{
${ }^{14}$ In other words, for a given sample, a weight equal to 1 is attached to the most recent observation. After a halflife period (e.g., 1 year $=252$ workdays), the weight exponentially decays to 0.5 .

${ }^{15}$ See Massey (2012).
} 
We built another signal based on Nautz and Strohsal (2015). The authors estimate by OLS a multiple regression between long-term inflation expectations and lag of long-term inflation expectations and surprises in macroeconomic variables. We tested for the possibility of structural breaks between the dependent variable and the regressors that measure macroeconomic surprises according to Andrews (1993) and Quandt (1960). ${ }^{16}$ We used as macroeconomic variables levels of nominal foreign exchange rate (R\$/US\$), Embi+Br and the yield of the 360 days interest rate swap. We considered a surprise in these macroeconomic variables when the value of the series is higher (or lower) than the mean of the series plus (minus) one standard deviation. Our coefficient of interest is the one related to the nominal foreign exchange rate.

We built a signal based on recursive logistic regressions, with equal weights for the time series observations, such as in Natoli and Sigalotti (2017). The model estimates the probability that four-year inflation expectations will be higher or lower than the $75 \%$ percentile of the workday distribution of this series (the dependent variable is 1 if it is higher and 0 if it is lower). This probability is estimated given that the one-year inflation expectations were higher or lower than the $75 \%$ percentile of the distribution of the same workday of this series (the regressor is 1 if it is higher and 0 if it is lower). Our coefficient of interest is the one related to the oneyear inflation expectations.

Figures 8, 9 and 10 show the evolution of the signals above - normalized z-scores with zero mean and standard deviation equal to 1 - of recursive regressions estimated with exponentially smoothed weights with half-life of one or two years or using weights from a rolling window of three years.

\subsubsection{Signals from market data}

In the case of market data, we built signals based on BEIs of one year and four years obtained in the swap and bond markets. Several of the signals were obtained in exact ways described in the previous section. We included two different signals from the survey signals: one is the difference between BEI and the inflation target and the other one is the square of this difference. Table 2 lists the market signals and Figures 11, 12 and 13 show the evolution of the market signals.

\footnotetext{
${ }^{16}$ In this paper, we employ the idea behind the Quandt-Andrews test, in which a single Chow (1960) breakpoint test is performed for every observation between two dates. The test statistics from those Chow tests are used to build dummy variables representing the different regimes between breakpoints.
} 


\subsubsection{Selection of signals based on correlation analysis}

We have a total of 31 signals: 17 are selected from survey data and 14 are selected from market data. To obtain our benchmark EAIs that we present in section 3.4, we select from these 31 signals the ones whose correlations are less than 0.7. Table 3 shows the correlation matrix of the selected signals. As a result, the following 14 signals were selected: S3, S9, S12, S13, S14, S15, S17, SM3, SM4, SM7, SM8, SM9, SM12 and SM14.

\subsection{Factor analysis}

Next, we employ factor analysis (FA) to extract common factors from the set of signals chosen. There are many ways suggested in the literature to combine the set of signals into a single indicator (e.g., equal weights or PCA - principal component analysis). We adopt the factor analysis ${ }^{17}$ setup, since our goal here is to build a single time series that reflects longterm anchoring of inflation expectations (in respect to short-run inflation expectations) by extracting common movements from the set of selected signals.

To do so, we use the "principal factors" as the factor extraction method and the "ordinary correlation" for covariance analysis. The idea is to obtain a vector of loadings that maximizes the cumulative communality using a number of $n$ factors. This way, each considered signal $\left(\mathrm{S}_{\mathrm{it}}\right)$ can be decomposed into a common component and an idiosyncratic component:

$$
\mathrm{s}_{\mathrm{it}}=\Lambda_{\mathrm{i}} \mathrm{F}_{\mathrm{t}}+\varepsilon_{\mathrm{it}}
$$

The common component captures the bulk of the covariation between $\mathrm{S}_{\mathrm{it}}$ and the other signals, whereas the idiosyncratic term affects only $\mathrm{S}_{\mathrm{it}}$ by assumption. Thus, it is simply a scaled common factor $\left(\mathrm{F}_{\mathrm{t}}\right)$, which is estimated using the entire set of signals. The long-term inflationanchoring indicator is defined to be this common factor.

\footnotetext{
${ }^{17}$ Factor analysis (FA) and principal component analysis (PCA) are similar statistical techniques in the sense that both generate linear combinations of the original series. However, PCA is used to retain the maximum amount of information from data in terms of total variation, whereas FA accounts for common variance. Thus, FA is often employed to build factors (latent variables), while PCA is often used in data reduction frameworks. See Johnson and Wichern (1992) for further details.
} 
We adopt here a parsimonious model with two factors $(n=2)$, since alternative models with more factors, in general, deliver estimations with higher uniqueness and lower communality (in the additional variables and/or factors) in relation of a model with fewer factors. ${ }^{18}$

As a result, the first factor accounts for $37 \%$ of the total variance of the set of 14 selected signals, whereas the first and second factors together represent $55 \%$ of the fraction of total variance. ${ }^{19}$ Next, we use those figures to build a combined single factor, as a linear combination of the two original factors, as follows: $\mathrm{F}_{\mathrm{t}}=\mathrm{F}_{1, \mathrm{t}} * 0.37 / 0.55+(1-0.37 / 0.55) * \mathrm{~F}_{2, \mathrm{t}}$. Table 4 summarizes the factor loadings and Figure 14 shows the factors in the baseline case.

\subsection{State-space model}

We build our expectations anchoring indexes based on the maximum likelihood estimation of a linear state-space model as described in the system of equations (2)-(3), presented next. The idea is to disentangle the fiscal policy effect from the common factor $F_{t}$, constructed in the previous section, and build a filtered anchoring indicator from the state-space model:

$$
\begin{aligned}
& \mathrm{x}_{\mathrm{t}}=\mathrm{Ax} \mathrm{x}_{\mathrm{t}-1}+\mathrm{B} \varepsilon_{\mathrm{t}} \\
& \mathrm{y}_{\mathrm{t}}=\mathrm{Cx}_{\mathrm{t}}+\mathrm{Dv}_{\mathrm{t}}
\end{aligned}
$$

where $x_{t}=\left[c_{t} ; f_{t} ; o_{t}\right]^{\prime}$ is a vector of states and $y_{t}=\left[z_{t} ; F_{t} ; 1_{t}\right]^{\prime}$ is a vector of observable variables, and $\varepsilon_{\mathrm{t}}$ and $\mathrm{v}_{\mathrm{t}}$ are uncorrelated Gaussian residuals. First, $\mathrm{c}_{\mathrm{t}}$ is the monetary policy (expectations anchoring) state of interest, $\mathrm{f}_{\mathrm{t}}$ is a state designed to capture the fiscal stance dynamics, and $o_{t}$ is an auxiliary state to include the intercepts in the equations.

In turn, $\mathrm{z}_{\mathrm{t}}$ is the consensus expectation (Focus survey) of primary fiscal balance as \% of GDP, one-year ahead, $\mathrm{F}_{\mathrm{t}}$ is the long-term anchoring factor, and $1_{\mathrm{t}}$ is a constant series with unit values to play the role of the intercept. The matrices A, B, C and D are $3 \times 3$ null matrices, except for eight parameters estimated by maximum likelihood (ML) within a standard Kalman filter.

$$
A=\left[\begin{array}{ccc}
\theta_{1} & 0 & 0 \\
0 & \theta_{2} & 0 \\
0 & 0 & 1
\end{array}\right] ; B=\left[\begin{array}{ccc}
1 & 0 & 0 \\
0 & 1 & 0 \\
0 & 0 & 0
\end{array}\right] ; C=\left[\begin{array}{ccc}
0 & \theta_{3} & \theta_{4} \\
\theta_{5} & \theta_{6} & \theta_{7} \\
0 & 0 & 1
\end{array}\right] \text { and } D=\left[\begin{array}{ccc}
\theta_{8} & 0 & 0 \\
0 & 0 & 0 \\
0 & 0 & 0
\end{array}\right]
$$

\footnotetext{
${ }^{18}$ We use the parsimonious number of two factors since they account for more than half of the fraction of total variance of the set of signals. Nonetheless, there are many alternative factor selection tools available in the literature, such as the ones proposed by Bai and $\mathrm{Ng}$ (2002) or Alessi, Barigozzi and Capasso (2010).

19 These figures are computed using the eigenvalues obtained in the solution of each factor's linear combination, as explained in Jolliffe (2002).
} 
Note that state $\mathrm{o}_{\mathrm{t}}=1_{\mathrm{t}}$ plays the role of the intercept and states $\mathrm{c}_{\mathrm{t}}=\theta_{1} \mathrm{c}_{\mathrm{t}-1}+\varepsilon_{1, \mathrm{t}}$ and $\mathrm{f}_{\mathrm{t}}=\theta_{2} \mathrm{f}_{\mathrm{t}-1}+$ $\varepsilon_{2, \mathrm{t}}$ are $\mathrm{AR}(1)$ processes with zero mean. On the other hand, the observable fiscal expectation $\left(\mathrm{z}_{\mathrm{t}}\right)$ is driven by the fiscal state $\left(\mathrm{f}_{\mathrm{t}}\right)$ plus an intercept and the idiosyncratic shock $\mathrm{v}_{1, \mathrm{t} .}$. The longterm anchoring factor $F_{t}$ is decomposed into two states, $c_{t}$ and $f_{t}$, which are designed to capture, respectively, the dynamics of monetary and fiscal policies.

$$
\begin{aligned}
& \mathrm{z}_{\mathrm{t}}=\theta_{3} \mathrm{f}_{\mathrm{t}}+\theta_{4}+\theta_{8} \mathrm{v}_{1, \mathrm{t}} \\
& \mathrm{F}_{\mathrm{t}}=\theta_{5} \mathrm{c}_{\mathrm{t}}+\theta_{6} \mathrm{f}_{\mathrm{t}}+\theta_{7}
\end{aligned}
$$

The following restrictions are employed in the ML estimation: $0<\theta_{1}<1 ; 0<\theta_{2}<1 ; \theta_{3}>0 ; \theta_{5}>0$; $\theta_{6}>0 ; \theta_{8}>0$, such that increases in the states $c_{t}$ and $f_{t}$ represent a better anchored expectations state and a better fiscal stance, respectively. Also note, from (5), that the fiscal expectations series $\mathrm{Z}_{\mathrm{t}}$ is not linked to the monetary policy state - which is a restriction adopted to properly identify the model parameters - and that there is no residual in (6) to guarantee that all the dynamics observed in the common factor $F_{t}$ are either driven by the monetary policy state or by the fiscal policy state. ${ }^{20}$

As is well known, the model described in the system of equations (2)-(3) has only one global maximum, so initial conditions of the state variable do not have any influence on its estimation by maximum likelihood, except maybe on the number of interactions until convergence is reached. ${ }^{21}$ Finally, the EAI is defined as the logit-transformed ${ }^{22}$ smoothed Kalman filtered state $c_{t}$. Table 5 presents the Kalman filter parameter estimates and Figure 15 exhibits the states and observable variables in the baseline case.

We should stress that the results obtained from the reduced-form model represented by equations (1) to (6) hinge on the assessment that the expectations anchoring indexes concerning monetary policy have been disentangled from fiscal policy. Our strategy to implement such separation of policies is based on a standard state-space model using survey and market data. We acknowledge that the simplified setup, due to several modelling assumptions, might not entirely purge the fiscal policy outlook from the proposed expectations

\footnotetext{
20 This assumption, in principle, could be relaxed by including an error term with zero mean and low variance (set as initial condition in the Kalman filter estimation).

${ }^{21}$ We limit to 1,000 the number of interactions of the maximum likelihood estimations. In all estimations presented in this paper, maximum likelihood converged before reaching the limit of interactions. For the Kalman filter, we considered the expectation of initial state vector equal to zero.

${ }^{22}$ To guarantee the EAI to be inside the $[0 ; 1]$ interval.
} 
anchoring index. ${ }^{23}$ The empirical results next presented should be interpreted with this caveat in mind.

\subsection{Baseline EAIs}

Our baseline EAIs are the ones in which we used both signals from survey and market data (total of 14 signals), selected with correlation analysis (see section 3.1.3). We create three versions of these indexes depending on whether the signals are constructed from recursive correlations (or regressions) weighting the observations with exponentially smoothed weights with half-life of one or two years or using a rolling window of three years (see Figure 16).

Because we have market data only starting from 2005, the baseline-EAIs start then. Overall, they indicate that, in the beginning of the sample (2005-2008), the degree of expectations anchoring showed a reasonably high and stable pattern. In other words, market inflation expectations reflected the commitment of the $\mathrm{BCB}$ to keep inflation at the center of the inflation target.

When the subprime crisis hit Brazil's economy, the expectations anchoring indexes dropped and only started to improve again in the second quarter of 2013, when a contractionist monetary cycle (increases in the Selic interest rate) took place. By the end of the sample (mid2017), the EAIs reached similar levels to those observed in the beginning of the sample, reflecting the $\mathrm{BCB}$ clear objective to curb inflation with the help of fiscal measures that intended to signal better public debt dynamics.

\footnotetext{
${ }^{23}$ For instance, the single fiscal expectations series, coupled with an autoregressive structure assumed for the fiscal state $\mathrm{f}_{\mathrm{t}}$, might not properly capture the core standpoint of fiscal policy. Alternative approaches to tackle this issue could consider, for instance, a state-space model containing an entire block of equations (instead of a single one) to model the fiscal policy in a disaggregate way. On the other hand, the set of observable variables could include data from credit default swaps and/or real interest rates (e.g., long-maturity forwards) or even risk premium estimates using satellite term-structure models.
} 


\subsection{Robustness analyses}

We conduct a robustness analysis in three main dimensions. First, we create two other groups of EAIs based only on survey data or on market data. Each one is divided into three other groups, again depending on whether the signals are created from recursive correlations (or regressions) in which observations are weighted by exponential smoothing with half-life of one or two years or a rolling window of three years. Figures 17 and 18 show the evolution of these EAIs.

The dynamics of survey-EAIs are similar to the baseline ones, with one important difference. Survey EAIs obtained with rolling windows are more volatile (in particular, after 2006) when compared to the other survey EAIs. We do not have a precise explanation for this. However, we suspect that this may have to do with the fact that we use binary survey signals, which may have had a greater impact on this EAI due to the rolling windows.

As a second robustness exercise, we estimate and remove from the breakeven inflation (BEI) series the risk premium, which is expected to be nontrivial, particularly in the short run. To do so, we regress each BEI series against an intercept and the cross-section interquartile range constructed from the survey-based inflation expectations data (using the same forecast horizon). For instance, in the case of the BEI from swaps with one year maturity, we use the following regression:

$$
B E I \operatorname{swap} 1 y(t)=a+b * I Q R 1 y(t)+e(t)
$$

The risk premium series is proxied by $\hat{b} * I Q R 1 y(t)$, whereas the BEI series without risk premium is given by $\hat{a}+e(t) .{ }^{24}$ In the case of BEI from bonds, we include an additional regressor to account for liquidity premium (given by the ratio between the market value of NTN-Bs and LTNs outstanding). Figure 19 shows the original BEI series and those without the risk premium. Figure 20 presents the effect of the risk premium extraction in the expectations anchoring index constructed with market data. They show similar dynamics to our baseline EAIs.

\footnotetext{
${ }^{24}$ The advantage of our approach is that the estimated risk premium is "model-free" in the sense that it is not grounded on a specific theoretical model, but instead is solely based on survey data at the micro level.
} 
The third robustness check consists of using a different method in the factor analysis. Instead of extracting two factors, we employ here the minimum average partial (MAP) criterion for selecting the number of factors. In the baseline case, the method suggests a single factor, which is used as $F_{t}$ in model (2)-(3). Figure 21 presents the expectations anchoring index obtained from the single factor using MAP; with a very similar trajectory compared to the baseline EAI.

\section{Conclusion}

According to Blinder (1998): "In the real world, credibility is not created by incentive compatible compensation schemes or by rigid precommitment. Rather, it is painstakingly built up by a history of matching deeds to words."

Our objective in this paper is to build expectations anchoring indexes for inflation in Brazil that are essentially driven from the BCB's ability to anchor long-term inflation expectations. The EAIs are smoothed Kalman filtered maximum likelihood estimates from a linear statespace model, which also includes expected fiscal dynamics from survey data. The model signals give information on the degree of long-term inflation expectation anchoring.

We derive our EAIs from surveys of inflation expectations and from market data. Although varying across specifications, the expectations anchoring indexes that we propose tend to display a downward trajectory, more clearly in 2009, and show a recovery starting in 2016 until the end of the sample (mid-2017).

Future extensions of the paper could include other signals of long-term inflation anchoring. We also think that our method can be extended to the creation of EAIs for other central banks around the world, despite different data on long-term inflation expectations from those we have in Brazil and used in this paper. 


\section{References}

Alessi, L., M. Barigozzi and M. Capasso. 2010. Improved Penalization for Determining the Number of Factors in Approximate Factor Models. Statistics \& Probability Letters 80 (2324), 1806-1813.

Andrews, D.W.K. 1993. Tests for Parameter Instability and Structural Change with Unknown Change Point. Econometrica 61(4), 817-858.

Bai, J., and S. Ng. 2002. Determining the Number of Factors in Approximate Factor Models. Econometrica 70(1), 191-221.

Barro, R. and D. Gordon. 1983. A Positive Theory of Monetary Policy in a Natural Rate Model. Journal of Political Economy 91(4), 589-610.

Bernanke, S., Ben. 2007. Inflation Expectations and Inflation Forecasting. Speech at the Monetary Economics Workshop of the National Bureau of Economic Research Summer Institute, Cambridge, Massachusetts.

Blanchard, Olivier. 2004. Fiscal Dominance and Inflation Targeting: Lessons from Brazil. National Bureau of Economic Research, NBER, Working Papers 10389.

Blackburn, K., Christensen, M. 1989. Monetary Policy and Policy Credibility: Theories and Evidence. Journal of Economic Literature 27(1), 1-45.

Blinder, A.S. 1998. Central Banking in Theory and Practice. Cambridge. The MIT Press.

Blinder, A.S. 2000. Central-Bank Credibility: Why Do We Care? How Do We Build It? American Economic Review 90(5), 1421-1431.

Bordo, D.M., Siklos, L.P. 2015. Central Bank Credibility: An Historical and Quantitative Exploration. NBER Working Paper n. 20824.

Buono, Ines and Formai, Sara. 2016. The evolution of the anchoring of inflation expectations. Questioni di Economia e Finanza (Occasional Papers) n. 321, Bank of Italy, Economic Research and International Relations Area.

Cecchetti, S.G., Krause, S. 2002. Central bank structure, policy efficiency and macroeconomic performance: exploring empirical relationships. Federal Reserve Bank of St. Louis Economic Review 84(4), 47-59.

Chow, G.C. 1960. Tests of Equality Between Sets of Coefficients in Two Linear Regressions. Econometrica 28(3), 591-605.

Clarida, R., and Waldman, D. 2007. Is Bad News About Inflation Good News for the Exchange Rate? NBER Working Paper n. 13010.

Cukierman, A., Meltzer, A. 1986. A Theory of Ambiguity, Credibility, and Inflation under Discretion and Asymmetric Information. Econometrica 54(5), 1099-1128. 
Davis, J. Scott. 2012. Re-establishing Credibility: The Behavior of Inflation Expectations in the Post-Volcker United States. Working Paper 117 Federal Reserve Bank of Dallas.

D'Amico, S., Kim, D.H., Wei, M. 2016. Tips from TIPS: the Informational Content of Treasury Inflation-Protected Security Prices. Federal Reserve Board. Finance and Economics Discussion Series n. 2014-024.

Demertzis, M., Marcellino, M., Viegi, N. 2012. A Credibility Proxy: Tracking US Monetary Developments. The B.E. Journal of Macroeconomics 12(1).

Dimitris, C., Dimitris, G., Jappelli, T., Rooij, M. 2016. Trust in the Central Bank and Inflation Expectations. Working Paper 537 De Nederlandsche Bank.

Gaglianone, W.P. 2017. Empirical Findings on Inflation Expectations in Brazil: a survey. Working Paper n.464, Central Bank of Brazil.

Garcia, M.G.P., Guillén, D.A. 2011. Expectativas Desagregadas, Credibilidade do Banco Central e Cadeias de Markov. Revista Brasileira de Economia 68(2), 197-223.

Gomme, P. 2006. Central Bank Credibility. Federal Reserve Bank of Cleveland Review.

Isaacson, W. 2004. Benjamin Franklin: An American Life. Simon and Schuster Editors.

Issler, J.V., Santos, A.F. 2017. Central Bank Credibility and Inflation Expectations: A Microfounded Forecasting Approach. Getulio Vargas Foundation. Mimeo.

Johnson, R. and D. Wichern. 1992. Applied Multivariate Statistical Analysis. Upper Saddle River, United States: Prentice-Hall.

Jolliffe, I.T. 2002. Principal Component Analysis. Second edition. New York, United States: Springer.

Kaseeream, I. 2012. Essays on the Impact of Inflation Targeting in South Africa. University of Zululand Working Paper.

Leal, A.R., Ranciaro, A.N., Tejada, C.A.O. 2012. Credibilidade Não Linear para as Metas de Inflação no Brasil. Anpec 2013 Anais.

Levieuge, G., Lucotte,Y., Ringuedé,S. 2015. Central Bank Credibility and the Expectations Channel: Evidence based on a new credibility index. Working Paper 209 Narodowy Bank Polski.

Lowenkron, A., Garcia, M.G.P. 2007. Monetary policy credibility and inflation risk premium: a model with application to Brazilian data. Textos para discussão n.543, Department of Economics PUC-Rio (Brazil).

Massey, F.J. Jr. 2012. The Kolmogorov-Smirnov Test for Goodness of Fit. Journal of American Statistical Association 46(256), 68-78.

Mendonça, H.F. 2004. Mensurando a Credibilidade do Regime de Metas Inflacionárias no Brasil. Revista de Economia Política 24(3), 344-350. 
Mendonça, H.F., Souza, G. 2007. Credibilidade do regime de metas para inflação no Brasil. Pesquisa e Planejamento Econômico 37, 247-282.

Mendonça, H.F., Souza, G. 2009. Inflation targeting credibility and reputation: The consequences for the interest rate. Economic Modelling 26(6), 1228-1238.

Nahon, B., Meurer, N. 2005. A Relação entre a Credibilidade do Banco Central e a Inflação no Brasil do Regime de Metas Inflacionárias. Encontro de Economia da Região Sul-ANPECSul.

Natoli, F., Sigalotti, L. 2017. A New Indicator of Inflation Expectations Anchoring. Working Paper n. 1996 European Central Bank.

Nautz, D., Strohsal, T. 2015. Are US inflation expectations re-anchored? Economics Letters 127, 6-9.

Quandt, R.E. 1960. Tests of Hypotheses that a Linear System Obeys Two Separate Regimes. Journal of the American Statistical Association 55(290), 324-330.

Sargent, T.J., Wallace, N. 1981. Some unpleasant monetarist arithmetic. Federal Reserve Bank of Minneapolis. Quarterly Review. Fall issue.

Shen, P. 2006. Liquidity Risk Premia and Breakeven Inflation Rates. Federal Reserve Bank of Kansas City, Economic Review, second quarter, 29-54.

Sicsú, J. 2002. Expectativas Inflacionárias no Regime de Metas de Inflação: uma análise preliminar do caso brasileiro. Economia Aplicada 6(4), 703-711.

Stock, J.H., Watson, M.W. 1996. Evidence on structural instability in macroeconomic time series relations. Journal of Business and Economic Statistics 14(1), 11-30.

Svensson, L.E. 1993. The Simplest Test of Inflation Target Credibility. NBER Working Paper n. 4604.

Teles, V.K., Nemoto, J. 2005. O Regime de Metas de Inflação do Brasil é crível? Revista Brasileira de Economia 59(3), 483-505.

Val, F.F., Gaglianone, W.P., Klotzle, M.C., Figueiredo, A.C.F. 2017. Estimating the credibility of Brazilian monetary policy using forward measures and a state-space model. Working Paper n. 463, Central Bank of Brazil.

Walsh, C. 1995. Optimal Contract for Central Bankers. American Economic Review 85(1), $150-167$. 


\section{Appendix - Tables and Figures}

Table 1 - Signals constructed from survey-based inflation expectations

\begin{tabular}{ccl} 
Group & Signals & Description \\
\hline 1 & $\mathrm{~s} 1$ & cross-section mean forecast long run - inflation target \\
1 & $\mathrm{~s} 2$ & cross-section median forecast long run - inflation target \\
1 & $\mathrm{~s} 3$ & cross-section standard deviation (forecast long run - inflation target) \\
1 & $\mathrm{~s} 4$ & cross-section inter-quartile range (forecast long run - inflation target) \\
\hline 2 & $\mathrm{~s} 5$ & recursive Pearson correlation between (cross-section mean) short and long run inflation expectations \\
2 & $\mathrm{~s} 6$ & recursive Pearson correlation between (cross-section median) short and long run inflation expectations \\
2 & $\mathrm{~s} 7$ & recursive Pearson correlation between (cross-section std.dev.) short and long run inflation expectations \\
2 & $\mathrm{~s} 8$ & recursive Pearson correlation between (cross-section inter-quartile range) short and long run expectations \\
\hline 3 & $\mathrm{~s} 9$ & recursive OLS regression with (cross-section mean) short and long run inflation expectations \\
3 & $\mathrm{~s} 10$ & recursive OLS regression with (cross-section median) short and long run inflation expectations \\
3 & $\mathrm{~s} 11$ & recursive OLS regression with (cross-section std.dev.) short and long run inflation expectations \\
3 & $\mathrm{~s} 12$ & recursive OLS regression with (cross-section inter-quartile range) short and long run inflation expectations \\
\hline 4 & $\mathrm{~s} 13$ & binary variable from the hypothesis test (Ho: median expectation = inflation target) for the long run expectations \\
4 & $\mathrm{~s} 14$ & binary variable from the hypothesis test Ho: distr(t) = distr(t-21) for the long-run cross-section distribution \\
\hline 5 & $\mathrm{~s} 15$ & Nautz and Strohsal (2015), fx-rate slope from OLS (median expectation, macro shocks) \\
\hline 6 & $\mathrm{~s} 16$ & Natoli and Sigalotti (2017), slope from logit regression, median inflation expectations (short, long)
\end{tabular}

Table 2 - Signals constructed from breakeven inflation (BEI) market data

\begin{tabular}{|c|c|}
\hline Signals & Description \\
\hline sm1 & slope from recursive OLS regression, BEI 4 years against BEI 1 year (swaps) \\
\hline sm2 & recursive correlation between BEI 4 years and 1 year (swaps) \\
\hline sm3 & Nautz and Strohsal (2015), fx-rate slope from OLS (BEI 4y swaps, macro shocks) \\
\hline sm4 & Natoli and Sigalotti (2017), slope from logit regression, $\Delta \mathrm{BEI}$ swaps (1y, 4y) \\
\hline sm5 & (BEI 4y swaps - inflation target) \\
\hline sm6 & $\left(\mathrm{BEl} 4 \mathrm{y}\right.$ swaps - inflation target) ${ }^{\wedge} 2$ \\
\hline sm7 & Demertzis et al. (2012), time-Varying VAR, BEl swaps (1y, 4y) \\
\hline sm8 & slope from recursive OLS regression, BEI 4 years against BEI 1 year (bonds) \\
\hline sm9 & recursive correlation between BEI 4 years and 1 year (bonds) \\
\hline sm10 & Nautz and Strohsal (2015), fx-rate slope from OLS (BEI 4y bonds, macro shocks) \\
\hline sm11 & Natoli and Sigalotti (2017), slope from logit regression, $\Delta \mathrm{BEI}$ bonds (1y, 4y) \\
\hline sm12 & (BEI 4y bonds - inflation target) \\
\hline sm13 & $(\mathrm{BEl} 4 \mathrm{y} \text { bonds - inflation target })^{\wedge} 2$ \\
\hline sm14 & Demertzis et al. (2012), time-Varying VAR, BEl bonds $(1 \mathrm{y}, 4 \mathrm{y})$ \\
\hline
\end{tabular}


Table 3 - Correlation matrix of selected signals (survey and market)

\begin{tabular}{|l|c|c|c|c|c|c|c|c|c|c|c|c|c|c|}
\hline & S3 & S9 & S12 & S13 & S14 & S15 & S17 & SM3 & SM4 & SM7 & SM8 & SM9 & SM12 & SM14 \\
\hline S3 & 1.00 & & & & & & & & & & & & & \\
\hline S9 & 0.30 & 1.00 & & & & & & & & & & & & \\
\hline S12 & -0.56 & -0.62 & 1.00 & & & & & & & & & & & \\
\hline S13 & 0.35 & 0.26 & -0.22 & 1.00 & & & & & & & & & & \\
\hline S14 & 0.16 & 0.00 & 0.01 & 0.08 & 1.00 & & & & & & & & & \\
\hline S15 & 0.00 & 0.26 & -0.31 & -0.11 & -0.21 & 1.00 & & & & & & & & \\
\hline S17 & 0.48 & 0.69 & -0.61 & 0.15 & 0.00 & 0.46 & 1.00 & & & & & & & \\
\hline SM3 & -0.07 & -0.04 & -0.22 & 0.03 & -0.33 & 0.51 & -0.15 & 1.00 & & & & & & \\
\hline SM4 & -0.34 & -0.43 & 0.39 & 0.00 & -0.16 & 0.07 & -0.68 & 0.54 & 1.00 & & & & & \\
\hline SM7 & -0.08 & -0.34 & 0.38 & 0.12 & -0.05 & -0.52 & -0.51 & 0.10 & 0.47 & 1.00 & & & & \\
\hline SM8 & -0.25 & -0.57 & 0.66 & 0.11 & -0.05 & -0.26 & -0.69 & 0.16 & 0.60 & 0.61 & 1.00 & & & \\
\hline SM9 & 0.08 & -0.08 & 0.29 & 0.38 & 0.15 & -0.65 & -0.31 & -0.48 & 0.01 & 0.47 & 0.52 & 1.00 & & \\
\hline SM12 & 0.30 & 0.25 & -0.63 & -0.01 & 0.16 & 0.13 & 0.34 & -0.21 & -0.41 & -0.57 & -0.66 & -0.23 & 1.00 & \\
\hline SM14 & -0.49 & -0.40 & 0.56 & 0.14 & 0.07 & -0.38 & -0.68 & -0.22 & 0.54 & 0.36 & 0.53 & 0.52 & -0.15 & 1.00 \\
\hline
\end{tabular}

Note: Only signals with pairwise absolute correlation below 0.7 are selected for the ES2y baseline case.

Table 4 - Factor model loadings (baseline ES2y)

\begin{tabular}{lcccc} 
Signal & Loadings F1 & Loadings F2 & Communality & Uniqueness \\
\hline S3 & -0.47 & 0.32 & 0.33 & 0.67 \\
S9 & -0.65 & 0.15 & 0.45 & 0.55 \\
S12 & 0.80 & -0.01 & 0.65 & 0.35 \\
S13 & -0.02 & 0.31 & 0.10 & 0.90 \\
S14 & -0.03 & 0.34 & 0.11 & 0.89 \\
S15 & -0.47 & -0.68 & 0.69 & 0.31 \\
S17 & -0.87 & 0.11 & 0.77 & 0.23 \\
SM3 & 0.02 & -0.83 & 0.69 & 0.31 \\
SM4 & 0.67 & -0.50 & 0.70 & 0.30 \\
SM7 & 0.67 & 0.11 & 0.47 & 0.53 \\
SM8 & 0.86 & -0.06 & 0.74 & 0.26 \\
SM9 & 0.50 & 0.71 & 0.75 & 0.25 \\
SM12 & -0.62 & 0.20 & 0.42 & 0.58 \\
SM14 & 0.74 & 0.19 & 0.59 & 0.41
\end{tabular}

Notes: Sample from September 28, 2005 to June 2, 2017 (2,916 workdays). Unrotated loadings and prior communalities via squared multiple correlation. The variation explained by the first factor is 37\%, whereas the first and second factors explain 55\% of total variance.

Table 5 - Kalman filter estimation of the expectations anchoring index (baseline ES2y)

\begin{tabular}{cccc} 
Parameter & Estimate & S.E. & \\
\hline$\theta_{1}$ & 0.9897 & 0.0004 & $* * *$ \\
$\theta_{2}$ & 0.9900 & 0.0004 & $* * *$ \\
$\theta_{3}$ & 5.7601 & 0.0682 & $* * *$ \\
$\theta_{4}$ & 5.8999 & 0.0669 & $* * *$ \\
$\theta_{5}$ & 1.5670 & 0.0105 & $* * *$ \\
$\theta_{6}$ & 1.0880 & 0.0552 & $* * *$ \\
$\theta_{7}$ & 0.2627 & 0.0016 & $* * *$ \\
$\theta_{8}$ & 0.0004 & 0.0546 &
\end{tabular}

Note: Sample from September 28, 2005 to June 2, 2017 (2,916 observations). ***indicates statistical significance at 1\% level. Only signals with pairwise absolute correlation below 0.7 are selected for the ES2y baseline case. The following signals are selected: S3, S9, S12, S13, S14, S15, S17, SM3, SM4, SM7, SM8, SM9, SM12 and SM14. 
Figure 1 - Survey-based inflation expectations, inflation target and tolerance bands

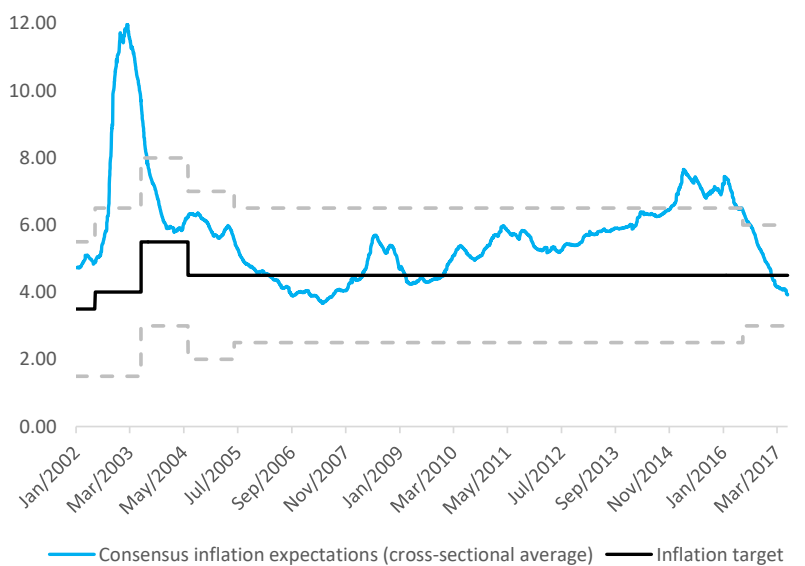

Notes: Average inflation expectations (Focus survey) with forecast horizon of 1 year.

Inflation targets and tolerance bands from http://www.bcb.gov.br/pec/metas/InflationTargetingTable.pdf

Figure 2 - Credibility indexes from the literature

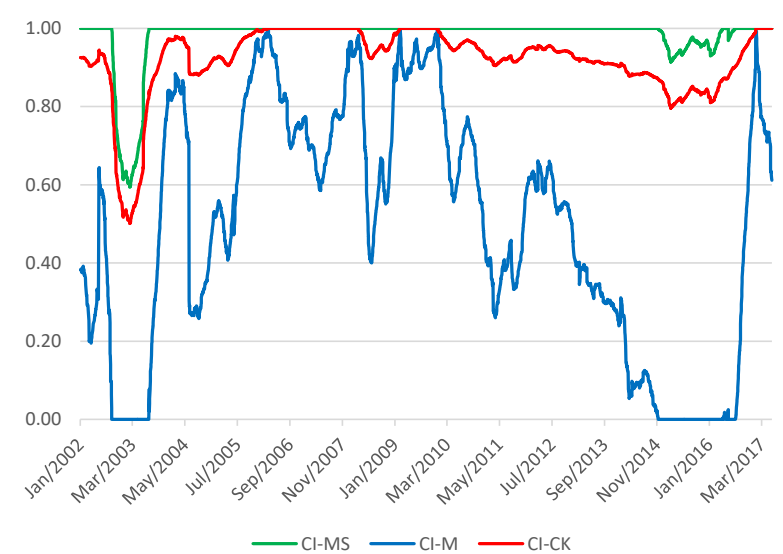

Notes: CI-CK means Cecchetti and Krause (2002), CI-M denotes Mendonça (2004) and CI-MS means Mendonça and Souza (2009). Inflation expectations are the survey-based cross-sectional average expectations with fixed horizon of 1 year. 
Figure 3 - Daily number of survey participants that report inflation forecasts for the current and the following calendar years (end-of-year fixed-event forecasts)

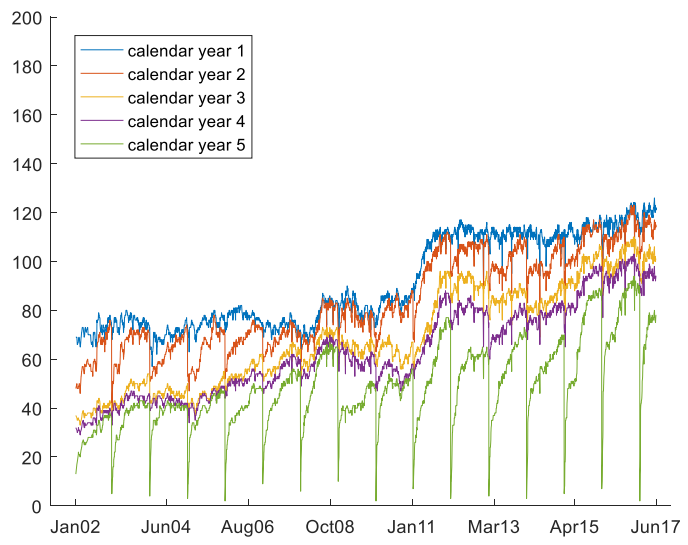

Source: Central Bank of Brazil and authors' calculations.

Figure 4 - Survey data: cross-sectional mean, median, standard deviation and inter-quartile range of individual survey-based inflation forecasts (fixed events)
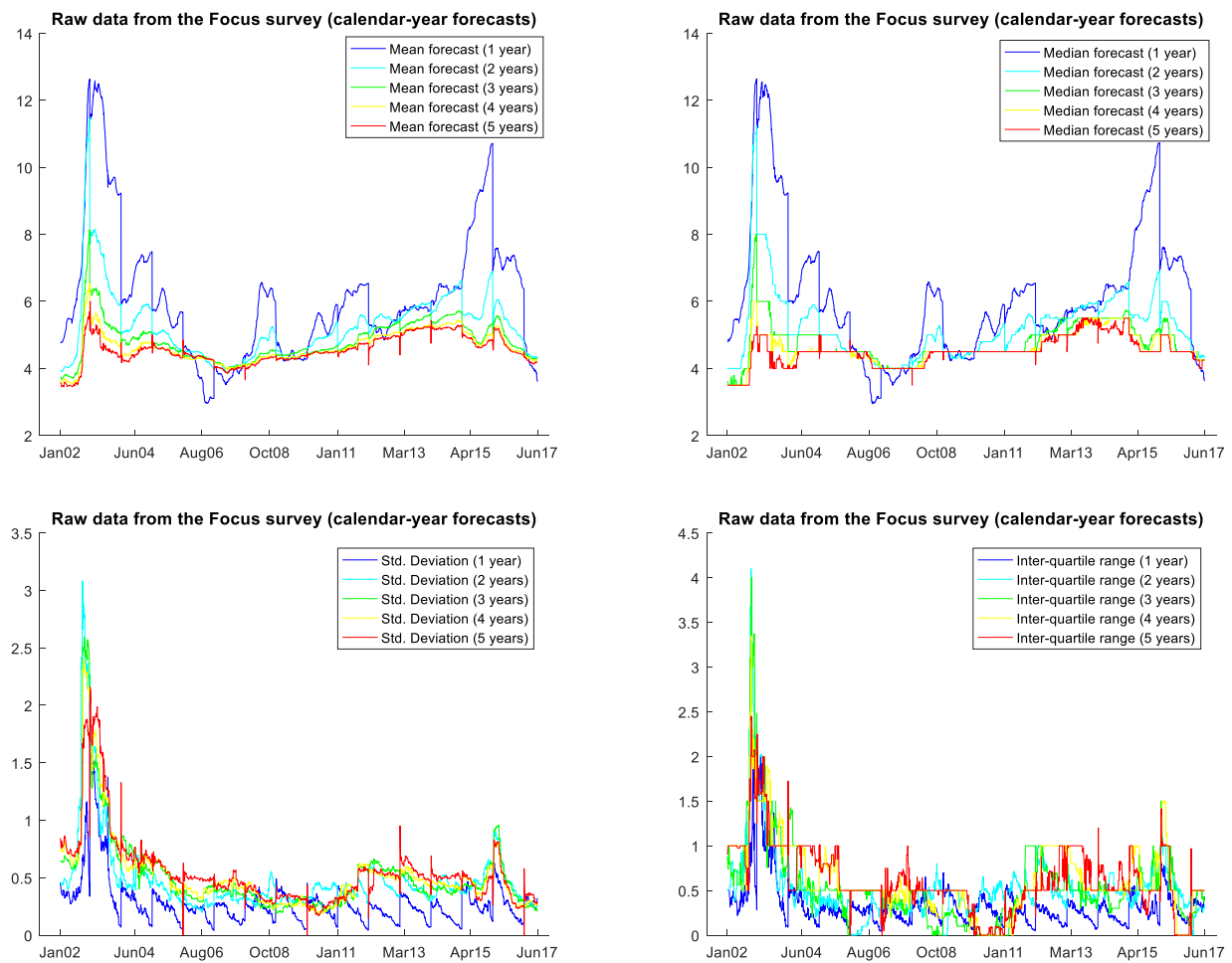

Source: Central Bank of Brazil and authors' calculations. 
Figure 5 - Survey data: cross-sectional mean, median, standard deviation and inter-quartile range of individual survey-based inflation forecasts (fixed horizons)
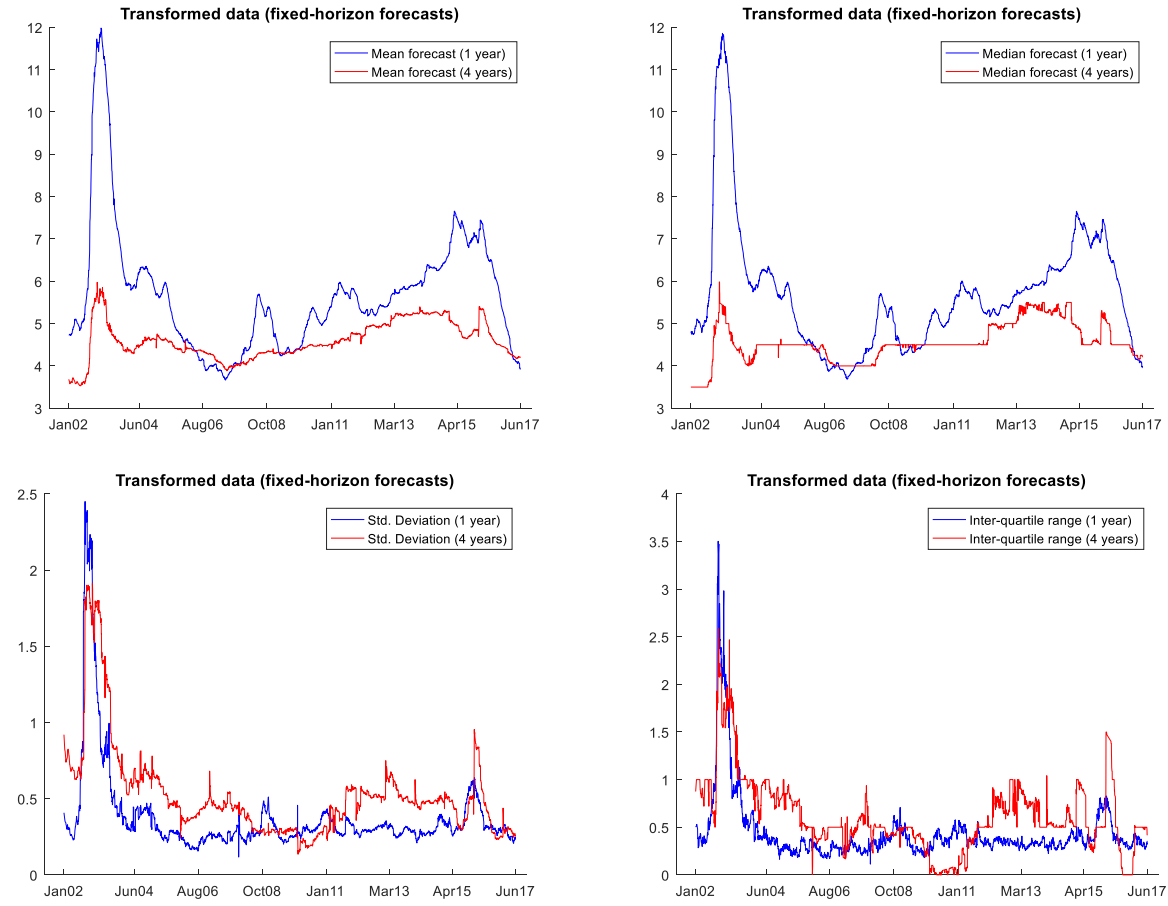

Source: Central Bank of Brazil and authors' calculations.

Figure 6 - Market data: breakeven inflation (BEI, \% 12 months)

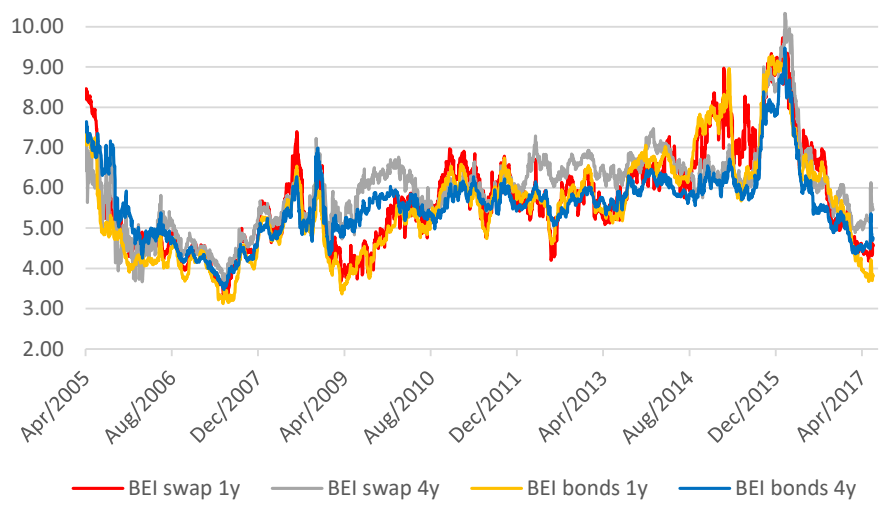

Source: Anbima, B3 and authors' calculations

Figure 7 - Consensus survey-based expectations of primary fiscal balance $\left(\mathrm{z}_{\mathrm{t}}\right)$ (\% of GDP, forecast horizon of 12 months)

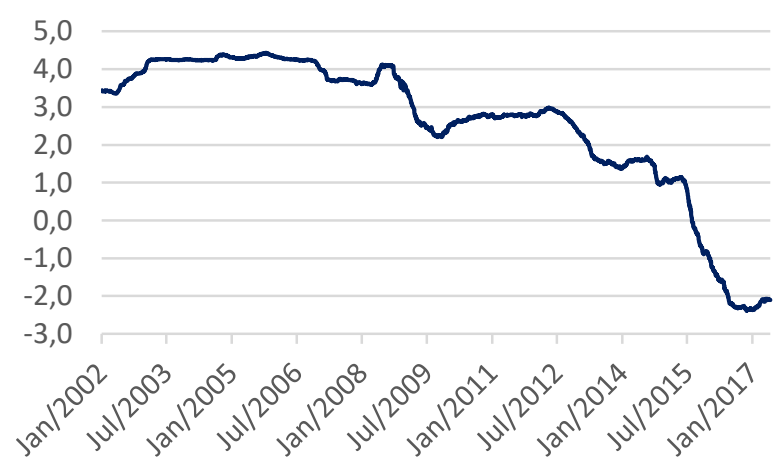

Source: Focus survey (BCB), cross-section average expectations. 
Figure 8 - Survey signals (exponential smoothing, half-life of 1 year)
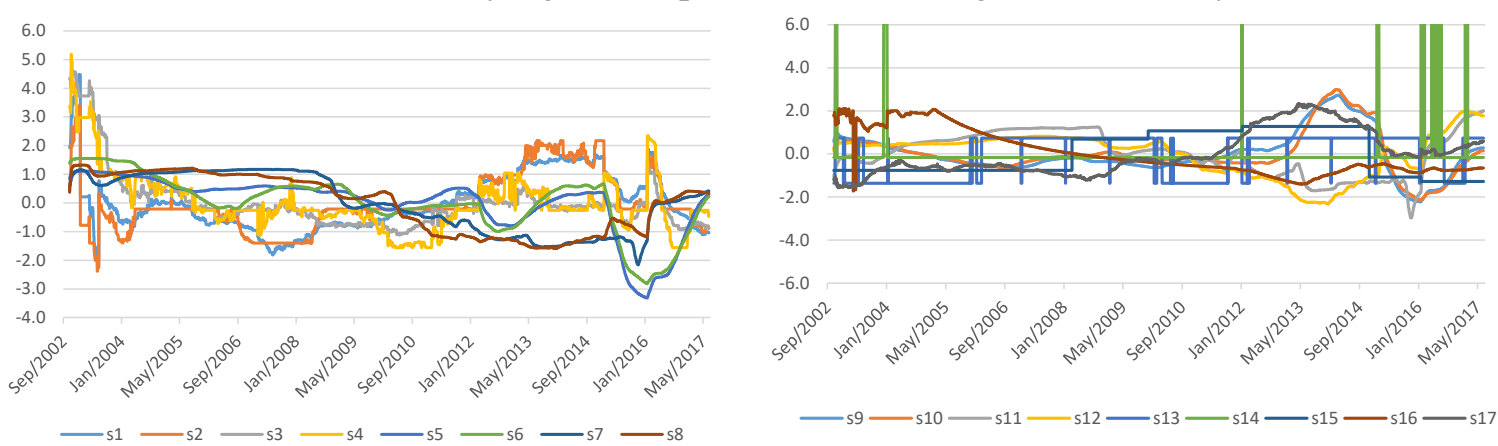

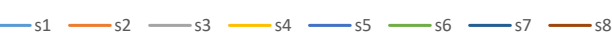

Figure 9 - Survey signals (exponential smoothing, half-life of 2 years)
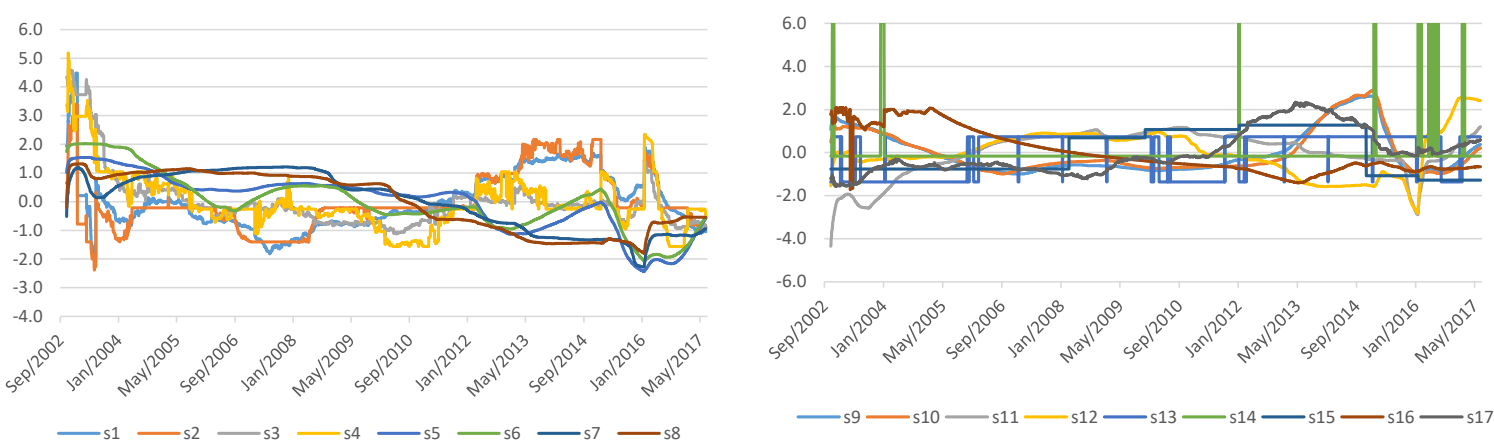

Figure 10 - Survey signals (rolling window weights, window of 3 years)
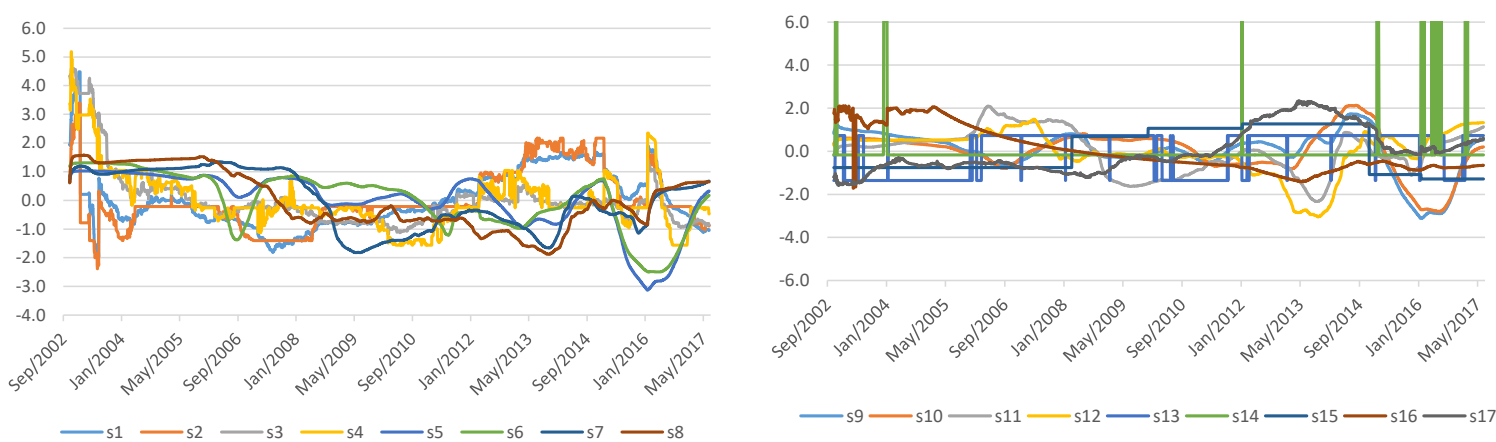
Figure 11 - Market signals (exponential smoothing, half-life of 1 year)
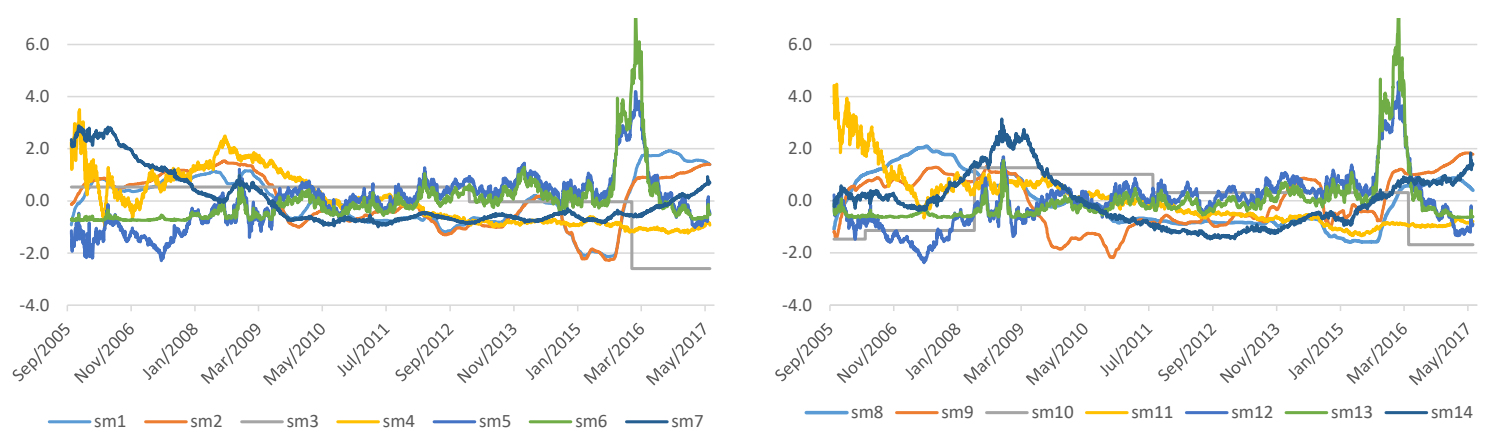

Figure 12 - Market signals (exponential smoothing, half-life of 2 years)
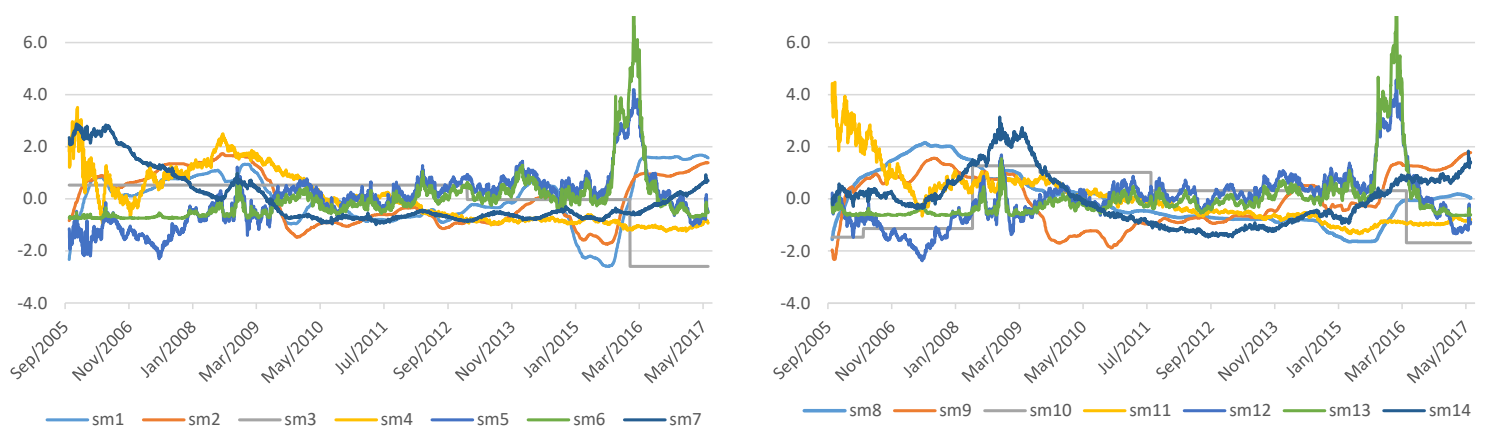

Figure 13 - Market signals (rolling window weights, window of 3 years)
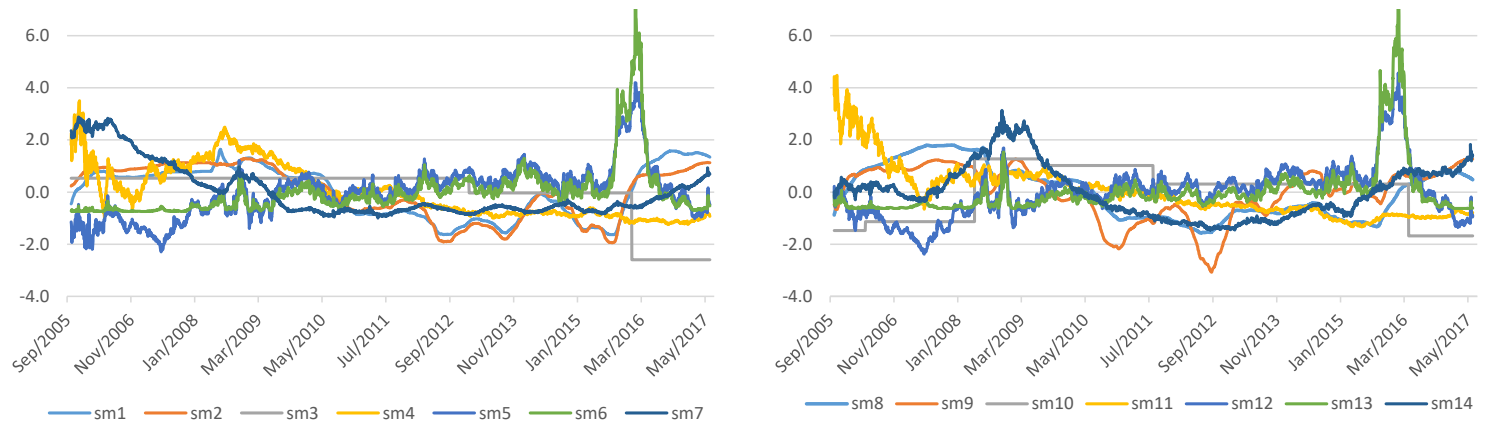
Figure 14 - Factors from long-term inflation expectation anchoring (baseline ES2y)

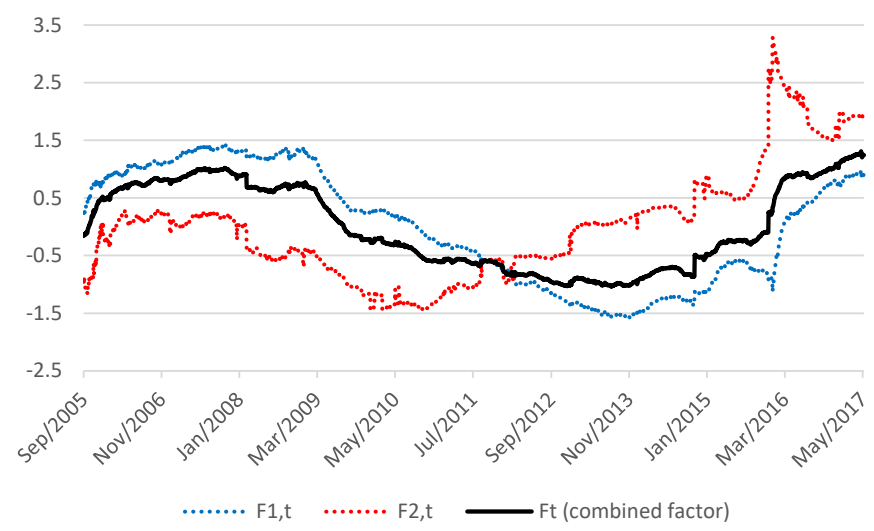

Figure 15 - Monetary policy state $\left(c_{t}\right)$, fiscal policy state $\left(f_{t}\right)$, expectation of primary fiscal balance $\left(\mathrm{z}_{\mathrm{t}}\right)$ and long-term anchoring factor $\left(\mathrm{F}_{\mathrm{t}}\right)$

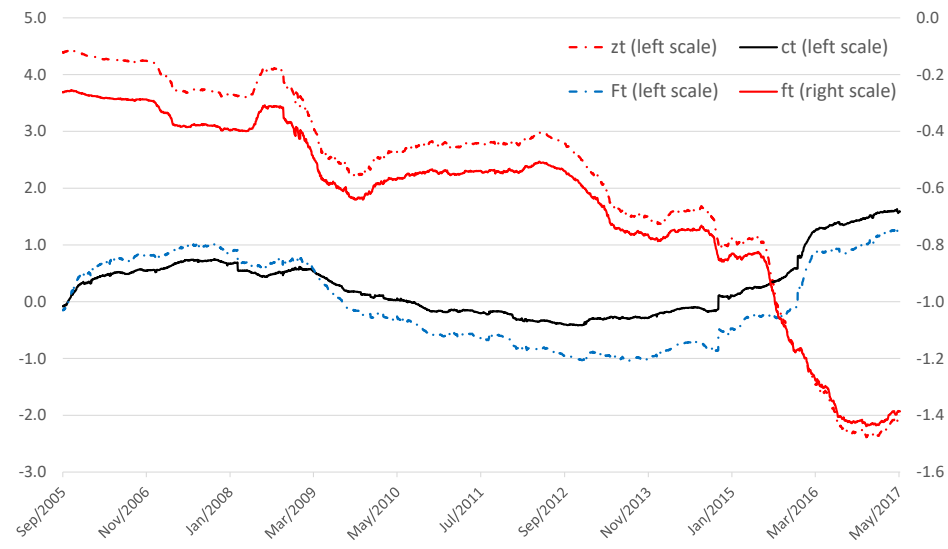

Figure 16 - Expectations anchoring index: baseline

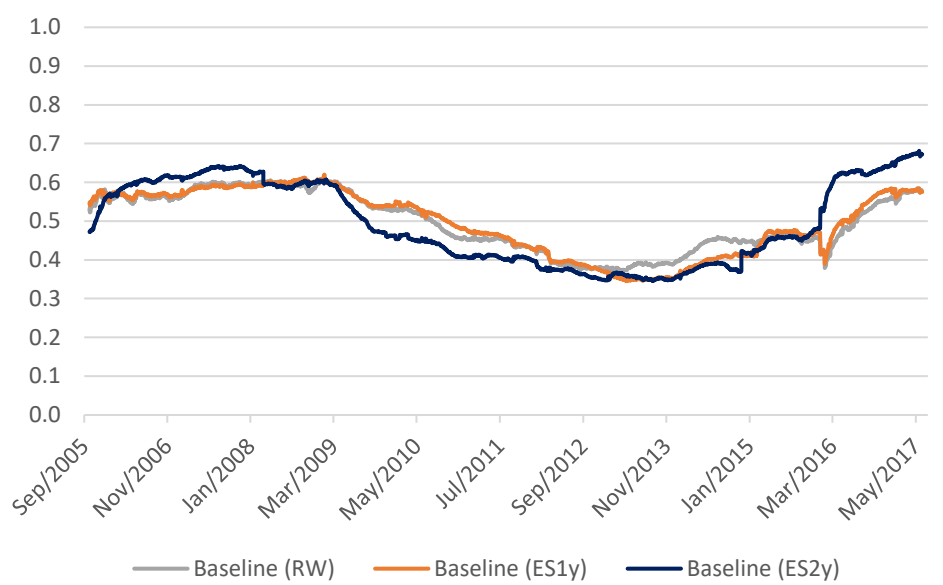

Notes: ES1y and ES2y denote the exponentially smoothed weights with half-life of 1 year and 2 years, respectively, and RW means rolling window weights (window of 3 years). Only signals with pairwise absolute correlation below 0.7 are selected for the baseline case. The following signals are selected: S3, S9, S12, S13, S14, S15, S17, SM3, SM4, SM7, SM8, SM9, SM12 and SM14. 
Figure 17 - Expectations anchoring index: market signals

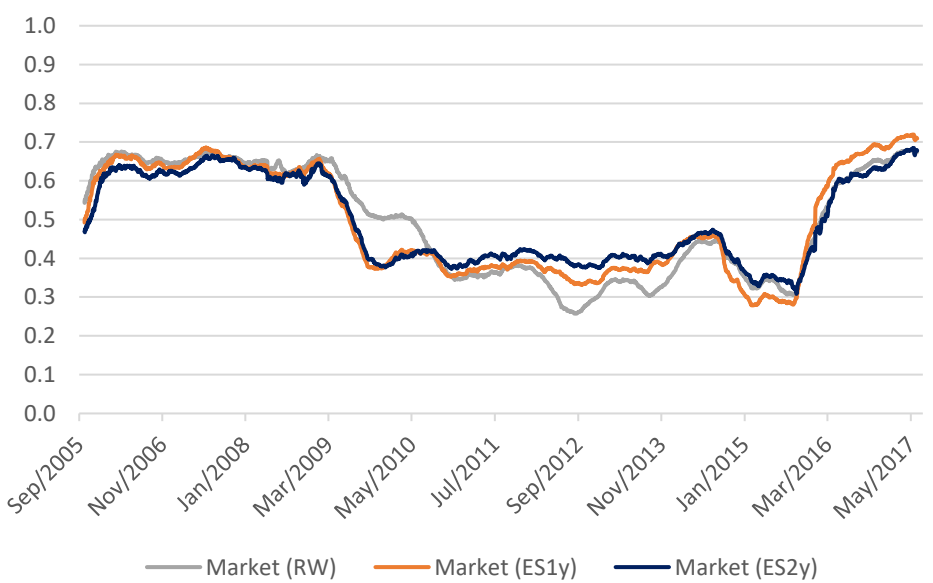

Notes: ES1y and ES2y denote the exponentially smoothed weights with half-life of 1 year and 2 years, respectively, and RW means rolling window weights (window of 3 years).

Figure 18 - Expectations anchoring index: survey signals

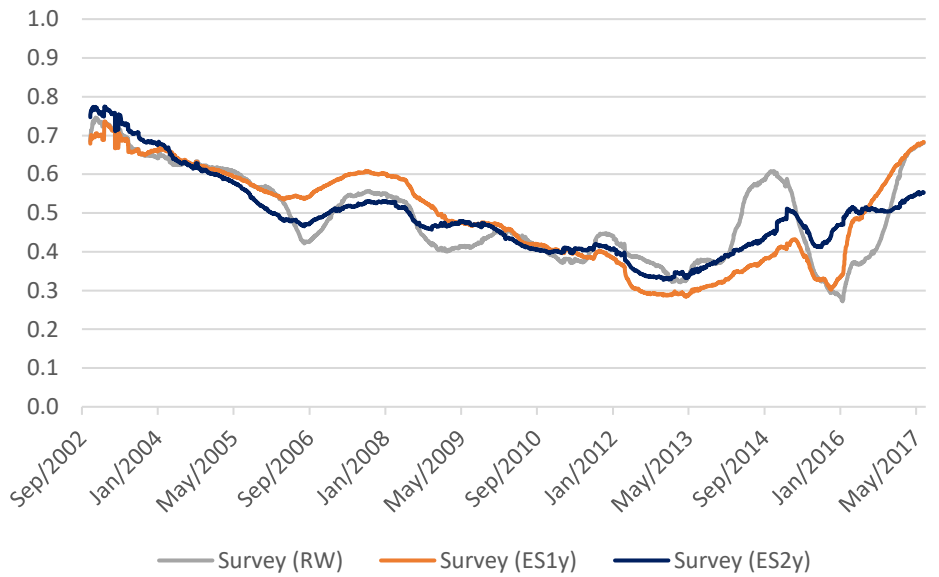

Notes: ES1y and ES2y denote the exponentially smoothed weights with half-life of 1 year and 2 years, respectively, and RW means rolling window weights (window of 3 years).

Figure 19 - Market data: breakeven inflation (BEI, \% 12 months) and risk premium extraction
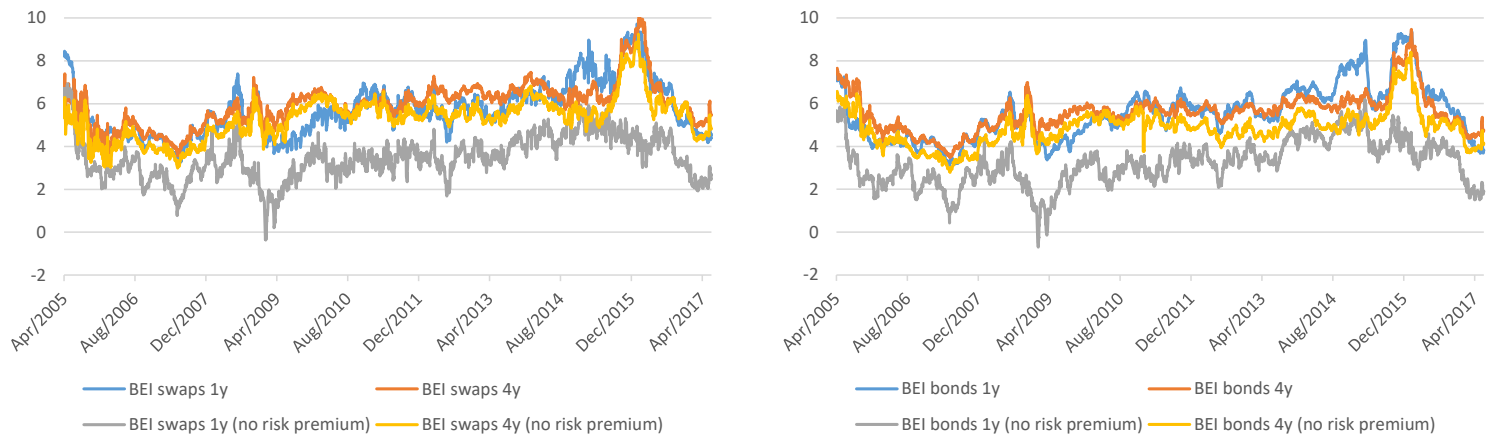
Figure 20 - Expectations anchoring index

and the effect of risk premium extraction from market data

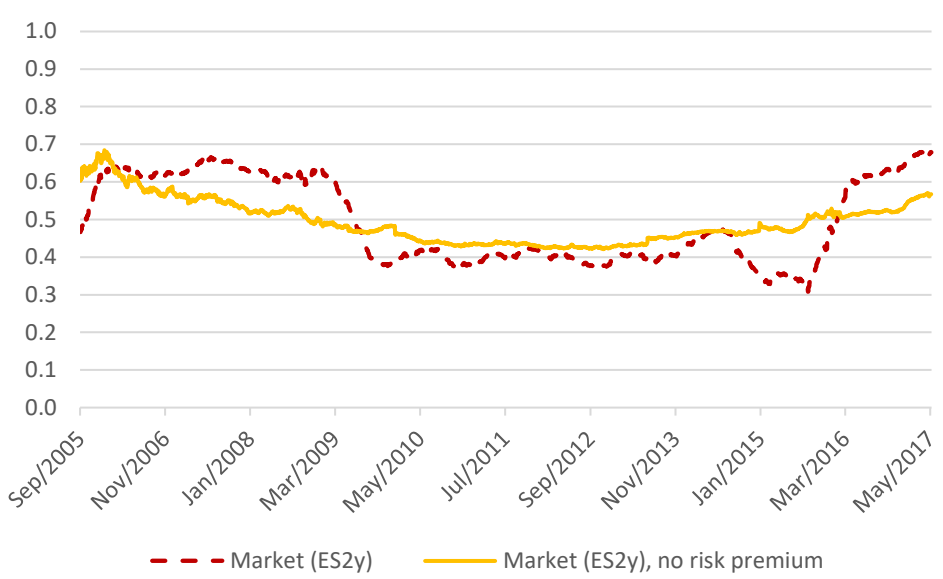

Figure 21 - Expectations anchoring index

using a different method to construct the common factor $\mathrm{F}_{\mathrm{t}}$

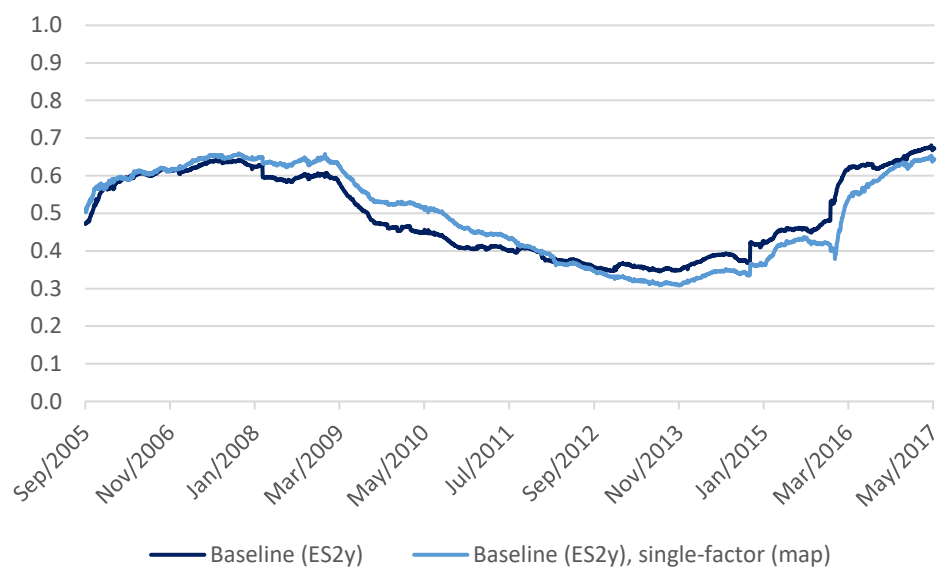

Note: The single-factor comes from the "minimum average partial" criterion for selecting the number of factors. 